\title{
The Readiness of Local KPU in Central Java to Organize the 2020 Simultaneous Election during COVID-19 Pandemic
}

\author{
Fitriyah $^{1}$, Nunik Retno Herawati ${ }^{2}$ \\ \{nunikretno92@gmail.com ${ }^{1}$ \} \\ Universitas Diponegoro, Indonesia ${ }^{1,2}$
}

\begin{abstract}
The focus of this study lies in the readiness of local KPUs in Central Java to organize the 2020 Simultaneous Election during the COVID-19 pandemic. KPU is the executor of the election act as the election is an important event to ensure the leadership succession goes smoothly by involving the community. The COVID-19 pandemic is an unpredicted event as the impact is extensive and the end of this pandemic is unforeseeable. The local KPUs are facing an unpleasant situation however they have no choice. This study uses online survey methods to collect primary data from 23th-28th June 2020 obtained from one KPU members for each 21 cities/regencies in Central Java which organized the local election.
\end{abstract}

Keywords: Local Election 2020, KPU Readiness, COVID-19

\section{Introduction}

One of the principles of election is to ensure that the General Election Committee (KPU) is professional. This principle is faced by many local KPUs especially those required to organize the 2020 simultaneous local election (Pilkada). According to the electoral calendar, at the end of 2020, the 2020 election is scheduled in 9 provinces, 224 regencies, and 37 cities which include $43 \%$ of all regions of Indonesia. All preparation has been carefully planned including financial preparation which went smoothly and faultlessly. The voting was scheduled on Wednesday, 23rd September 2020 from which all electoral stages are subsequently scheduled according to the Local Election Act No. 10 Year 2016.

The situation changed 180 degrees when at the end of March 2020, the government officially announced 'work from home' (WFH) regulation due to the coronavirus disease pandemic (COVID-19 pandemic), in which all mass-involving activities should be stopped including all electoral stages which were on progress. After vacuuming for 3 months in an unsafe situation the government released the Government Regulation in Lies of Law (Perppu) No. 2 Year 2020 and decided that the local election remains organized in 2020 and the voting was scheduled on 9th December 2020 by ensuring health protocols observance in all electoral stages. Since 15th June 2020, all electoral stages were re-initiated started by revision of the schedule and budget revision by KPU to ensure the health protocols are implemented.

The professionalism of KPU is again tested as usual since KPU also faces tests in all elections. The most common tests are the amendment of election regulation released shortly before the organization. In almost every election period, the rules for the elections/Pilkada are revised through a legislative review by the House of Representatives (DPR) and the 
government as well as a judicial review requested by groups or individuals. The KPU as the implementer of the election laws only has the option of implementing election/regional election laws. Another form of test, in the event of a disaster, the election/regional election can be postponed in all regions or parts of the region due to a disaster. Experience showed that postponement of elections/regional elections due to natural disasters was limited to certain areas and when the disaster ends can be known. Disasters due to the COVID-19 pandemic are different, as currently the KPU is facing disasters throughout the region and when the disaster ends is unknown. This means that currently, the KPU is working during a disaster situation, not after a disaster as before.

Based on the description above, the 2020 Pilkada is important to observe, since there are conditions that are challenging for the election organizers due to the COVID-19 pandemic which has multi-effect effects, such as the condition of the readiness of the (regional) government for additional temporary budgets of the Regional Budget (APBD) funds which are the source of Pilkada funding. It has likely been reallocated to deal with the COVID-19 pandemic, therefore finding the source of the additional Pilkada budget would be a challenge. The next is regarding the readiness of the organizers after being vacuumed due to the postponement of the elections. Based on PKPU No.5 of 2020, starting from 15th June 2020, the local KPUs began to continue the Pilkada stages that had been postponed, as well as the challenge to ensure the safe implementation of the 2020 Pilkada at all stages. The KPU ensured that the simultaneous regional elections were carried out following the health protocol for handling COVID-19.

The 2020 Pilkada in Central Java was attended by 21 regencies/cities. Of these, there were 14 incumbents $(66.7 \%)$ who were suspected of returning to the nomination, and it is estimated that 6 regions were only followed by a single candidate, namely the City of Semarang, Boyolali, Sragen, Wonogiri, Grobogan, and Rembang. Based on the data related to the challenges of organizing the 2020 Pilkada that have been described, the readiness for the 2020 Pilkada in Central Java is worthy of research.

\section{Research Methods}

This research was conducted using an online survey. Data collection was carried out online on 23-28th June 2020 to the regency/city KPUs in Central Java, which will hold the 2020 Pilkada. The respondents of this study were one of five KPU members for each 21 regions. We performed the unit analysis in which the institution (KPU) was represented by its members. Data analysis was performed in the form of a frequency table using SPSS.

\section{Results and Discussion}

\subsection{Professionalism of KPU}

The smooth administration of election with its dynamics is determined by the capacity of the election organizer. According to Sardini to deal with complexity, it is necessary for election administrators who control election administration to have adequate capacity, and integrity, or in other words professional [1]. 
There are three forms of election management bodies, namely independent, government, and mixed institutions [2]. All three have been used in Indonesia at different times. The government-controlled model occurred during the New Order, the mixed model (a combination of government and elements of society) at the beginning of the reformation, and starting from the 2004 General Election the election organizers were independent. This independent nature has an impact on the recruitment pattern of KPU members, which is a merit system, prioritizing capacity, integrity, and professionalism. Because the Indonesian KPU is national and permanent, the independent network of the KPU can be maintained down to the village level [3]. This character has saved the election administration in Indonesia, where the election is considered the most complex. The complexity is not only in the choice of mixed election designs but also the regulatory factors which are often revised through legislative reviews or judicial reviews [4][5]. There are three election organizers in Indonesia, namely the general election commission (KPU), the election supervisory body (Bawaslu), and the election organizer's honor council (DKPP) with different functions and roles. KPU is an institution that carries out election administration, whose work is supervised by Bawaslu, which also supervises the implementation of the election. Meanwhile, DKPP oversees the ethical behavior of KPU and Bawaslu members. This composition creates checks and balances in election administration [6].

\subsection{The 2020 Pilkada Map in Central Java}

Central Java did not have a bad record during the post-reform elections/Pilkada. When the first direct elections were held in 2005 , there were indeed anarchic protests but on a small scale and were localized in the KPU offices or regional government offices. The elections/Pilkada outside that year went well. The number of voters in Central Java, (27.9 million in the 2019 Election) was ranked $3^{\text {rd }}$ in Indonesia behind East Java and West Java Provinces. In the 2020 Pilkada, Central Java will hold regional elections in 21 regencies/cities or $60 \%$ of the total 35 regencies/cities. This means that almost all regional elections in Central Java will be completed in 2020, thus involving a large number of voters. This large figure is not a worry, given the previous election/regional election experience. Voters in Central Java have tested their political maturity with a minimum of electoral/Pilkada conflicts.

In the 2020 Pilkada in Central Java, 14 incumbents will run again, and 6 of them are predicted to be the sole candidates. There are two potential violations that Bawaslu is always wary of, namely mobilizing voters with money politics and mobilizing bureaucracy. Muhtadi studies have indeed found money politics to be found in all elections in Indonesia [7]. Rahman's study for Central Java in Blora found this phenomenon [8]. Fitriyah's study in Pati also found the same thing [9]. Meanwhile, bureaucratic mobilization is something that should be expected to be rampant with the incumbent as a candidate. Currently, the potential for violations by the incumbent has started through a covert campaign when carrying out assistance programs for people affected by COVID-19.

On the other hand, the relatively calm condition can be established by the growing potential of single candidates in several regions. This demonstrates that more cooperation is built through coalitions between parties in the region, rather than competition. Experience showed that fierce competition between candidates and their supporters existed when there were only two contestants who equally strong. In addition, even if identity politics is used, the potential for social division in Central Java has not been detected so far.

Based on the location setting as described above, it seems that Central Java is a safe field that supports the successful implementation of the regional elections. Local KPUs in Central 
Java benefit from this condition. In the COVID-19 pandemic situation, the KPU can concentrate more on organizing it with relatively minimal external environmental disturbances. However, the factor of legal certainty from regulatory sources continues to overshadow the quality of the Pilkada. The COVID-19 pandemic has an impact on postponing regional elections for a while. Based on the Perppu, the KPU is returning to work on organizing the 2020 Pilkada since the Perppu had mandated a vote on $9^{\text {th }}$ December 2020 . The lifting of the postponement has made the KPU prepared to hold another election, including revising the election schedule and other KPU regulations (PKPU) that adjust the voting date. There are potentials for ill-prepared events to occur due to all changes made by the KPU, so that malpractice possibly occur in the implementation of the 2020 Pilkada. Surbakti defines malpractice as an act of violation of election integrity, whether intentional or not, legal or illegal [10].

\subsection{Measuring the Readiness of KPU}

How the readiness of local KPU in Central Java in organizing the 2020 Pilkada during the COVID-19 pandemic would be answered in this study. The stages of the election have been initiated since January 2020 and voting was scheduled on 23rd September 2020. At the end of March 2020, the electoral stages were all refrained due to the COVID-19 pandemic.

Officially through the KPU decision Number: 179/PL.02-kpt/01/KPU/III/2020, the 2020 Pilkada will be postponed. According to the schedule, several stages of the 2020 Pilkada that are running and being stopped were the inauguration of the Voting Committee (PPS), verification of the independent candidate supporting requirements, the establishment of voter data updating officers (PPDP), and the implementation of checking and research, as well as updating and compiling voter lists. When the Pilkada stage reopened on June 15, 2020, 21 regions that had the 2020 Pilkada in Central Java had completed the formation of the PPK and PPS ad hoc Pilkada bodies, they had been inaugurated and worked and previously given Pilkada training or technical guidance (Bimbingan Teknis or Bimtek). While the formation of PPDP is in process, 6 regions have already moved to form PPDP in some areas although according to the schedule the formation of PPDP is on $24^{\text {th }}$ June-14 ${ }^{\text {th }}$ July 2020 . This data shows the readiness of the KPU in Central Java to form an ad hoc institution. The formation of this ad hoc agency went well because the recruitment process for PPK and PPS had been completed before the delay, what was slightly delayed was the implementation of Bimtek for PPS, which had been completed only in 17 regions. Two regions have just been implemented in some of their districts while two other regions have not been implemented at all. The KPU in the four regions has planned to immediately implement Bimtek using digital media.

One of the keys to successful regional elections is budget adequacy. According to the schedule for the 2020 Pilkada stages, the deadline for signing the regional grant agreement (NPHD), which is the basis for the regional election budget, is on $14^{\text {th }}$ October 2019. In almost all regions, the KPU and the local government have signed the NPHD. In Central Java, all regions organizing the Pilkada have also completed budget issues. Budget problems only emerged after the delay. Based on the Perppu No. 2 Year 2020, the Pilkada was held with due observance to health protocols, which had an impact on the budget increase. Budget changes were related to the personal protective equipment (PPE) expenditures for field officers and later for voters, as well as reducing the number of voters at polling stations (TPS) by increasing the number of TPS.

Of the 21 regions that organize the 2020 Pilkada in Central Java, only one region did not submit an additional budget. The amount of application for additional budget varied, some 
required a small addition, less than $5 \%$ but some reached more than $45 \%$. The attitudes of the local governments also varied as some approved while some only partially approved, or even rejected. The request for an additional budget is an urgent need, especially to meet the need for the provision of personal protective equipment's (PPE) for officers in the field, as stated by the respondent, the request for an additional budget that was rejected would make it difficult for the organizers to work.

Table 1. The Approval of Additional Budget Increase in Central Java

\begin{tabular}{|c|c|c|c|c|c|c|}
\hline $\begin{array}{c}\text { Percentages of } \\
\text { Budget Increase }\end{array}$ & $\begin{array}{c}\text { Approved } \\
\mathbf{1 0 0 \%}\end{array}$ & $\begin{array}{c}\text { Approved } \\
\mathbf{5 1 - 7 5 \%}\end{array}$ & $\begin{array}{c}\text { Approved } \\
\mathbf{2 6 - 5 0 \%}\end{array}$ & $\begin{array}{c}\text { Approved } \\
\mathbf{1 - 2 5 \%}\end{array}$ & $\begin{array}{c}\text { Not } \\
\text { Approved }\end{array}$ & Total \\
\hline Not proposing & - & - & - & - & - & 1 \\
\hline $5-15$ & 3 & - & 1 & - & 1 & 5 \\
\hline $16-30$ & 3 & 1 & 2 & - & - & 6 \\
\hline $31-45$ & 2 & 1 & 2 & - & - & 5 \\
\hline$>45 \%$ & 2 & 1 & 1 & - & - & 4 \\
\hline Total & $10(47,6)$ & $3(14,3)$ & $6(28,6)$ & - & $1(4,8)$ & 21 \\
\hline
\end{tabular}

There was a special treatment related to additional budget sources, since in the normal condition the source of Pilkada funds is from the Regional Government Budget (APBD), in an abnormal situation such as the COVID-19 pandemic, the additional budget can be received from the National Government Budget (APBN). Some regions receive additional budget support from the APBD for some of their budget needs, the rest were requested from the APBN, whose submission is facilitated by the National KPU RI. Currently, the budget from the APBN has been partly disbursed to finance the verification stages of independent candidates and voter data matching and research, and also PPE provision to adhere with the health protocols. In addition to the adequacy of the budget, the readiness of disbursement needs to be ensured according to the needs of each stage. It turned out that not all regions were ready, 4 regions are recognized by respondents as being less/ not ready which had an impact on the less optimal work of the particular KPUs.

The implementation of the Pilkada stages that meets the health protocol requirements also required the dissemination of information to the wider community. The continuing increase in the number of COVID-19 sufferers was thought to have an impact on community participation. The KPU, which is holding regional elections, is required to build public trust about the guarantee of a safe Pilkada. Pilkada socialization is no longer limited to election information but also information on applied health protocols. The KPU's obstacle to outreach is the limited number of meetings involving the masses which were limited to a maximum of 20 people attending each meeting. Meanwhile, the use of digital media is network constrained and not all voters use and understand digital media. Complaints of this obstacle to socialization were conveyed by all respondents.

During the WFH period, people became accustomed to using video conferencing services to hold meetings, as there were various options such as Microsoft, Teams, Zoom, and Google Meet. The local KPUs used this service to hold coordination meetings with the election stakeholders, namely regional head and deputy regional head candidate pairs, supporting political parties, campaign teams, success teams, Bawaslu, local governments, police, etc., including goods and services providers and election logistics. All KPU offices were equipped with the necessary equipment to hold the coordination meeting using a video conferencing service application. Several stages require coordination meetings involving the stakeholders, such as nominations, campaigns, procurement and distribution of logistics, 
voting and vote recapitulation, and election disputes. Readiness for coordination meetings using video conferencing was stated by all respondents.

Pilkada which are synonymous with activities that involve large numbers of masses or mass mobilization [11] have become the activities that are limited by the number of participants and the COVID-19 health protocol must be applied to ensure a safe Pilkada which is not easy. The description above shows several obstacles for the particular KPUs that are starting to emerge. Pilkada quality is also determined by the accuracy of voter data, previous election/regional election experience, in which the accuracy of voter data is a source of election disputes and conflicts. While in the normal conditions, the poor record of voter data remains a problem, it is suspected that the situation for the COVID-19 pandemic has worsened. PPDP officers are supposed to collect data on voter's door to door, but it is risky for now. Door-to-door (direct-selling) campaigns and mass gatherings have also become the most popular campaign strategies, however, the current conditions are also not supportive. In this context, the incumbent benefits because he already has social investment during his tenure, besides that the incumbent also benefits from various policy programs handling the impact of COVID-19 in various forms of direct assistance to the community. The limited form of campaigning by election participants as well as socialization by the KPU to voters will have an impact on the degree of their participation.

The complexity of elections is thus not only a matter of the electoral system which creates complexity for administrators and voters but also the environmental situation when elections/ regional elections are held. The COVID-19 pandemic has made the holding of elections/regional head elections more complex, which will have an impact on the quality of the Pilkada itself. In this situation, an election organizer with capability, integrity, and professionalism is needed. This research shows that the KPU as an institution is institutionalized and therefore ready to face various potential threats, but the work of the KPU is also determined by resources, which not all are under the KPU's control.

\section{Conclusion}

The government's policy to hold the 2020 Pilkada in 2020 has a risk that the quality of the elections is potentially worse than the previous elections/Pilkada which were generally considered successful. Several obstacles have begun to be faced by the KPU as the organizer of the Pilkada, which were generally the result of the COVID-19 pandemic. This research shows that the KPU institution has been institutionalized, the KPU has been tested as a professional institution, but the work of the KPU is also influenced by the readiness of resources, which are not all under the KPU's control. This research shows that the Central Java KPUs were ready to hold the 2020 Pilkada.

\section{References}

[1] N. H. Sardini, "Desain Kelembagaan Penyelenggara Pemilu Tahun 2019: Struktural dan Fungsional," in Serial Evaluasi Penyelenggaraan Pemilu Serentak 2019: Perihal Para Penyelenggara Pemilu, A. Perdana, Ed. Jakarta: Bawaslu, 2019.

[2] A. Wall, Electoral management design: The international IDEA handbook. International Institute for Democracy and Electoral Assistance ..., 2006.

[3] R. Surbakti and K. Nugroho, "Studi Tentang Desain Kelembagaan Pemilu yang Efektif," 2015.

[4] A. Khoirunissa, Evaluasi Pemilu Serentak 2019: Dari Sistem Pemilu Ke Manajemen 
Penyelengaraan Pemilu. Jakarta: Perludem, 2020.

[5] P. S. Chaniago, "Evaluasi Pilkada Pelaksanaan Pilkada Serentak Tahun 2015," Polit. Indones. Indones. Polit. Sci. Rev., vol. 1, no. 2, pp. 196-211, 2016.

[6] N. H. Sardini, Penyelenggara Pemilu Di Dunia: Sejarah, Kelembagaan, dan Praktik Pemilu di Negara Penganut Sistem Pemerintahan Presidensial, Semipresidensial, dan Parlementer. Jakarta: Dewan Kehormatan Penyeleggara Pemilu (DKPP RI), 2015.

[7] B. Muhtadi, Vote Buying in Indonesia: The Mechanics of Electoral Bribery. Springer Nature, 2019.

[8] N. Rahman, "Pati, Jawa Tengah: Target, Teknik dan Makna dari Pembelian Suara," Polit. Uang di Indones. Patronase dan Klientelisme pada Pemilu Legis. 2014, pp. 329-352, 2015.

[9] F. Fitriyah, "Cara Kerja Politik Uang (Studi Kasus Pilkada dan Pilkades di Kabupaten Pati)," Polit. J. Ilmu Polit., vol. 6, no. 2, pp. 101-111, 2015.

[10] R. Surbakti, A. G. Karim, K. Nugroho, A. Sujito, and H. Fitrianto, Intregritas Pemilu 2014: Kajian Pelanggaran, Kekerasan, dan Penyalahgunaan Uang pada Pemilu 2014. Kemitraan bagi Pembaruan Tata Pemerintahan, 2014.

[11] R. Surbakti, "Pemilu sebagai Mobilisasi Warga dan Logistik," Media Indonesia, 2019. 